\title{
JV TASK 28 - ASSESSMENT OF SUBSURFACE FATE OF MONOETHANOLAMINE AT SOUR GAS PROCESSING PLANT SITES-PHASE III
}

\section{Topical Report}

Prepared for:

Federal Energy Technology

AAD Document Control

U.S. Department of Energy

PO Box 10940, MS921-143

Pittsburgh, PA 15236-0940

DOE Contract No. DE-FC21-93MC30098--63

Performance Monitor: Dr. Mildred Perry
Prepared by:

James A. Sorensen

Energy \& Environmental Research Center

University of North Dakota

PO Box 9018

Grand Forks, ND 58202-9018 


\section{TABLE OF CONTENTS}

LIST OF TABLES $\ldots \ldots \ldots \ldots \ldots \ldots \ldots \ldots \ldots \ldots \ldots \ldots \ldots \ldots \ldots$

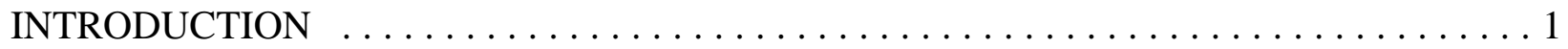

BACKGROUND $\ldots \ldots \ldots \ldots \ldots \ldots \ldots \ldots \ldots \ldots \ldots \ldots \ldots \ldots \ldots \ldots$

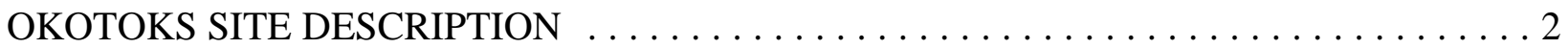

NATURE AND EXTENT OF SOIL CONTAMINATION $\ldots \ldots \ldots \ldots \ldots \ldots \ldots \ldots$

PHASE I RESEARCH $\ldots \ldots \ldots \ldots \ldots \ldots \ldots \ldots \ldots \ldots \ldots \ldots \ldots \ldots \ldots \ldots$

RESULTS OF PHASE I SLURRY EXPERIMENTS $\ldots \ldots \ldots \ldots \ldots \ldots \ldots \ldots \ldots$

PHASE II RESEARCH $\ldots \ldots \ldots \ldots \ldots \ldots \ldots \ldots \ldots \ldots \ldots \ldots \ldots \ldots \ldots \ldots$

RESULTS OF PHASE II LANDFARMING EXPERIMENTS $\ldots \ldots \ldots \ldots \ldots \ldots \ldots \ldots$

PHASE III RESEARCH $\ldots \ldots \ldots \ldots \ldots \ldots \ldots \ldots \ldots \ldots \ldots \ldots \ldots \ldots$

BIOPILE DESIGN AND OPERATION $\ldots \ldots \ldots \ldots \ldots \ldots \ldots \ldots \ldots \ldots \ldots \ldots$

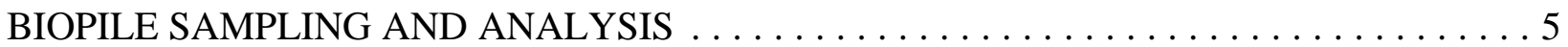

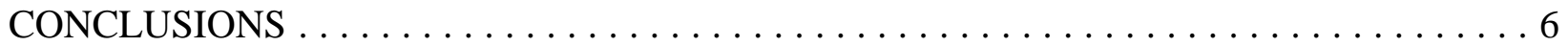

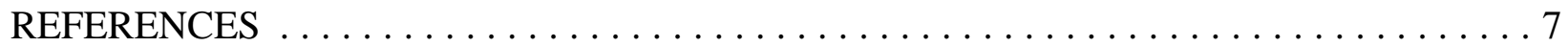

\section{LIST OF TABLES}

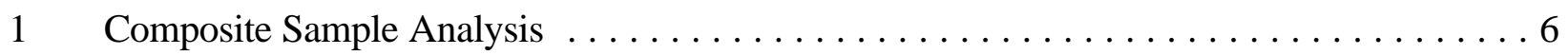




\section{JV TASK 28 - REMEDIATION STRATEGIES FOR SOILS CONTAMINATED WITH AMINE-BASED GAS-SWEETENING WASTES}

\section{INTRODUCTION}

Alkanolamines are commonly used by the natural gas industry to remove hydrogen sulfide, carbon dioxide, and other acid gases from the natural gas in which they occur ("sour" gas if hydrogen sulfide is present). At sour gas-processing plants, as at all plants that use alkanolamines for acid gas removal (AGR), spills and on-site management of wastes containing alkanolamines and associated reaction products have occasionally resulted in subsurface contamination that is presently the focus of some environmental concern. In 1994, the Energy \& Environmental Research Center (EERC) initiated a three-phase program to investigate the natural attenuation processes that control the subsurface transport and fate of the most commonly used alkanolamine in Canada, monoethanolamine (MEA). Funding for the MEA research program was provided by the U.S. Department of Energy (DOE), Canadian Association of Petroleum Producers (CAPP), Canadian Occidental Petroleum Ltd. (CanOxy), Gas Research Institute (GRI), Environment Canada, and the National Energy Board of Canada. The MEA research program focused primarily on examining the biodegradability of MEA and MEA-related waste materials in soils and soil-slurries under a variety of environmentally relevant conditions, evaluating the mobility of MEA in soil and groundwater and the effectiveness of bioremediation techniques for removing contaminants and toxicity from MEA-contaminated soil.

The presently inactive Okotoks sour gas-processing plant, owned by CanOxy in Alberta, Canada, was the source of samples and field data for much of the laboratory-based experimental work and was selected to be the location for the field-based efforts to evaluate remediation techniques.

The objective of the research program is to provide the natural gas industry with "real world" data and insights developed under laboratory and field conditions regarding the effective and environmentally sound use of biological methods for the remediation of soil contaminated with amine-related wastes.

\section{BACKGROUND}

The operation of acid gas removal units creates a variety of wastes that may be introduced to the environment. The managed and unmanaged waste streams may be composed of spent alkanolamines, sludges from process unit tank bottoms, and process system filters. Unmanaged waste streams, particularly spills during changeover operations (the process of exchanging spent chemical for fresh chemical), may also include fresh alkanolamines. Thermal/oxidative (T/O) reaction products are typically present in the waste streams in varying concentrations, depending on the process conditions. Additional components of the wastes include additives such as corrosion inhibitors and antifoaming agents, benzene, and trace metals (Sorensen et al., 1998). 
The release of these waste streams to the subsurface environment is generally controlled by waste management techniques. Most gas-sweetening facilities today employ techniques that minimize or eliminate the release of amine-related waste to the environment. However, past management practices may have resulted in significant subsurface impacts at some sites.

\section{OKOTOKS SITE DESCRIPTION}

The decommissioned Okotoks sour gas-processing plant, owned by CanOxy near Calgary, Alberta, was chosen as the study site for the MEA research program. The Okotoks plant is located approximately $25 \mathrm{~km}$ south of Calgary and $1 \mathrm{~km}$ east of the town of Okotoks in south central Alberta. The Okotoks site can be physiographically divided into two areas, the terrace uplands, in which the plant facilities, landfill, and MEA-sludge disposal pits are located, and the river valley in the area of the sulfur block, south of the plant. The contaminated soil samples used in the laboratory-based research activities were taken from the terraced uplands portion of the site.

\section{NATURE AND EXTENT OF SOIL CONTAMINATION}

Up to four former amine pits were identified at the Okotoks site from aerial photographs (Shoal Environmental Consultants Ltd., 1994). These pits were mainly used to store tank bottom sludges from the amine regeneration process. The four sludge disposal pits had been constructed sequentially from 1967 to 1974 . By the time the pits were closed in 1984, they contained an estimated 2000 to 3000 barrels of MEA process waste. Upon closure, the liquid and sludge contents of the pits were removed, with the liquids being injected into the site's salt-water disposal well and the sludges being spread on the fire breaks around the plant and on the sulfur base pad. The pits were then backfilled and reclaimed. The results of an environmental assessment conducted in 1992 as part of the plant's decommissioning process revealed the presence of a layer of sludge-contaminated material at a depth of 2 to $3 \mathrm{~m}$ in the area of the former amine sludge disposal pits. A strong ammoniacal odor in the sediments and elevated total organic nitrogen concentrations suggested that the contamination was MEA-related.

In 1997, a variety of soil samples were collected at Okotoks for organic and inorganic characterization of the amine-related contamination. Contaminated materials from the MEA pit were sampled at depths of up to $3.5 \mathrm{~m}$, depending on where the contaminated material was encountered, which was primarily determined by the presence of an ammonia smell generally associated with MEA. Qualitative gas chromatography-mass spectroscopy (GC-MS) analysis of a soil sample from the MEA pit revealed numerous peaks, including naphthalene, C2naphthalenes, dibenzothiophene, and a significant amount of (hydroxyethyl)imidazolidone $\mathrm{N}$ (HEI), an MEA T/O reaction product. Additional compounds were tentatively identified as benzothiazole, methylthiophenes, and methylbenzothiophenes. Methylene chloride extracts from Okotoks amine pit soil were also analyzed quantitatively by IC (ion chromatography). The IC analysis detected an MEA concentration of approximately $300 \mathrm{mg} / \mathrm{L}$ in the MEA pit sediment sample extract. 


\section{PHASE I RESEARCH}

As described above, considerable quantities of amine sludge-contaminated soil are present at the Okotoks site. In 1994 and 1995, experimental activities were conducted at the EERC to evaluate the biodegradability of MEA sludge-contaminated soil in slurry bioreactors. The slurry experimental activities were designed to provide estimates of 1) the time required to initiate the biodegradation, 2) the rates of degradation of the contaminants, 3) the degree of difficulty in operation, and 4) the composition of the material remaining after slurry treatment.

Analysis of COD (chemical oxygen demand), TKN (total Kjeldahl nitrogen), and ammonia were by standard methods (American Public Health Association, 1992).

\section{RESULTS OF PHASE I SLURRY EXPERIMENTS}

Soil contaminated by MEA-related sludge biodegraded well for the first 15 days, but metabolism was slower thereafter. Operation of the bioreactors for 24 days reduced the COD and organic nitrogen concentration $79 \%$ and $59 \%$, respectively, at $8 \%$ soil concentration. COD removals were approximately the same at all three slurry concentrations. TKN reductions indicated toxicity that resulted in reduced removals at higher slurry concentrations. The complete data set from these experimental activities is provided in Gallagher and coworkers (1996). In general, the results of the Phase I bioslurry experiments suggest that land treatment of the MEAcontaminated soils may be a technically viable remediation technique.

\section{PHASE II RESEARCH}

Landfarming experiments conducted as part of Phase II were designed to examine the effectiveness of land treatment for reducing MEA-related contamination and toxicity in soil from the Okotoks site. The following are the key variables chosen to be evaluated in these tests: 1) phosphorus dose, 2) tillage frequency, 3) loading rate of contaminated soil, and 4) $\mathrm{pH}$ adjustment. Samples from the beginning and end of the study period were analyzed for toxicity, COD, and TKN. Detailed descriptions of the experimental designs and methods are provided in Gallagher and Sorensen (1997).

\section{RESULTS OF PHASE II LANDFARMING EXPERIMENTS}

The results of the landfarm experiments showed that the most important variable affecting bioremediation was soil loading. Increases in phosphorus resulted in increases in ammonia, suggesting that bioactivity increased. With regard to contaminant removal, the most effective landfarm removed $51 \%$ of the initial COD, $68 \%$ of the initial TKN, and $66 \%$ of the organic nitrogen. The data showed that toxicity of some components in the contaminated soil resulted in reduced bioactivity, longer lag times, and reduced removals. Based on the bacterial luminescence test $\left(\right.$ Microtox $\left.^{\circledR}\right)$, toxicity in all landfarms at the lower soil loadings (10 and $17.5 \mathrm{wt} \%$ ) was 
reduced to zero. However, the results of additional assessments via seed emergence, root elongation, and earthworm survival suggested that significant toxicity remains even in the lower soil-loading conditions. Further testing showed that the toxic fraction of the treated soil is extractable in both water and methanol, which suggests that those components may be leachable from the soil. The identity of these toxic components is not known.

\section{PHASE III RESEARCH}

While the laboratory-scale landfarming technique evaluated in Phase II successfully removed much of the contamination, including toxicity determined by Microtox ${ }^{\circledR}$, considerable toxicity, as determined on the basis of root elongation, seed emergence, and earthworm survival, was observed in the remaining material. The water-soluble nature of the toxic components in the contaminated soils indicates that they may be concentrated in leachate generated during bioremediation. Based on the toxicity data, a system that is designed with a leachate collection system, such as an engineered biopile, may be a viable bioremediation technique.

Activities conducted under Phase III of the research program are primarily field-based investigations designed to evaluate the effectiveness of an engineered biopile for the remediation of MEA-contaminated soils. In the spring of 1998, a demonstration-scale biopile operation was designed by the EERC and Hazco Environmental Services of Calgary. In the summer of 1998, Hazco constructed the biopile, and operation was initiated on August 5.

\section{BIOPILE DESIGN AND OPERATION}

The biopile containment cell measures $40 \mathrm{~m}$ long by $10 \mathrm{~m}$ wide by $1.5 \mathrm{~m}$ deep. Above a 25 mil reinforced polyethylene (RPE) liner is a thin layer of crushed gravel. Filter fabric caps the gravel layer and lies directly beneath the treatment soils. The soil layer is gently mounded and enclosed by a 25-mil RPE cover. The biopile also contains irrigation and aeration systems as well as a leachate sump unit , and a leachate collection tank, air blower unit, electrical supply, freshwater supply tank, and water-pumping system are located in close proximity.

Approximately $450 \mathrm{~m}^{3}$ of treatment soils and $50 \mathrm{~m}^{3}$ of straw are housed within the constructed cell. Soil additives include $2.58 \mathrm{~m}^{3}$ of calcium chloride $\left(\mathrm{CaCl}_{2}\right)$ as well as $10-34-00$ (\% nitrogen-phosphorus-potassium) liquid fertilizer $(\approx 2036 \mathrm{~kg})$. Straw was added to act as a bulking agent, thereby increasing the porosity and permeability of the biopile. The addition of $\mathrm{CaCl}_{2}$ effectively increases the permeability of the soil, thus allowing water to move more easily through the biopile. Fertilizer was added as a nutrient source for the microbial population to improve the biodegradation rate.

Aeration, irrigation, and a leachate collection system define the dynamic components of the structure. Aeration is performed to supply oxygen to the microbial population, which, in turn, enhances biodegradation. The aeration system is one large air vent $(100-\mathrm{mm}$ perforated PVC pipe) and four equally spaced flow ducts $(50-\mathrm{mm}$ perforated pipe) that run the entire 40-m length. 
The flow ducts are powered by an external blower unit. Adequate soil moisture is also necessary to obtain appropriate microbial activity, although if the soil is saturated or nearly so, aeration will be inhibited. Therefore, water is periodically added to the biopile using an irrigation system. The irrigation system comprises five semipermeable hoses, equally spaced, which also run the full length of the structure. The hoses are fed by an external freshwater supply (2000 imperial gallons), powered by a water-pumping system. The results of the toxicity evaluations conducted as part of the Phase II activities indicate that the toxic fraction of the soil contamination is watersoluble; therefore, collection of the leachate generated during biopile operation is necessary. Leachate is collected by a sump unit housed directly below the crushed gravel layer and temporarily stored in a reinforced external tank (2000 imperial gallons). For the Okotoks site, leachate is disposed of in an injection well located on-site.

Construction of the biopile was initiated on July 13 and completed on July 20, 1998. The aeration system was activated and the first 2000 gallons of water were added to the biopile on August 5, 1998. Another 2000 gallons of water were incorporated into the biopile on September 25, 1998.

\section{BIOPILE SAMPLING AND ANALYSIS}

Upon completion of biopile construction and immediately prior to the beginning of active operation (wetting and aeration), samples of biopile material were collected for baseline analyses. A composite sample was submitted to a commercial laboratory in Calgary for the following analyses: hydrometer sediment size analysis, $\mathrm{pH}$, conductivity, saturation, sodium adsorption ratio, bulk density, moisture weight, soluble salts, and elemental composition. The results of these analyses are given in Table 1. Separate samples were collected and analyzed for ammonium, nitrate+nitrite-N, and TOC (total organic carbon).

Once the wetting and aeration operations began, the project work plan called for soil samples to be collected on a biweekly basis. The biopile has been divided into eight sections, and the biweekly soil samples were collected from three randomly selected sections during each sampling event. One sample each was taken from the upper $60 \mathrm{~cm}$ and the lower $60 \mathrm{~cm}$ of each biopile section. The biweekly samples are analyzed for TKN, ammonium $\left(\mathrm{NH}_{3}-\mathrm{N}\right)$, nitrate+nitrite$\mathrm{N}\left(\mathrm{NO}_{\mathrm{x}}-\mathrm{N}\right)$, and TON (total organic nitrogen), which are considered the key soil character parameters for evaluating the general activity of the biopile over the course of the study period.

Three thermocouples were placed inside the biopile to monitor temperature on a regular basis. Soil moisture was measured biweekly to determine the frequency of wetting. Samples of leachate generated during the operation of the biopile were scheduled to be collected after the first week of operation (August 1998), just prior to winter shutdown (late October 1998), after spring start-up (April 1999), and, finally, at the close of the field-based operations (June or July 1999). Toxicity tests will be conducted on samples of soil and leachate collected at the beginning and end of the biopile operation. 
TABLE 1

Composite Sample Analysis

\begin{tabular}{lcll}
\hline Hydrometer Sediment Analysis & & & \\
$\quad$ Sand, \% & 34.3 & & \\
Silt, \% & 28.6 & & \\
Clay, \% & 37.1 & & \\
Particle Size & Clay Loam & & \\
Salinity & & Elemental Composition, mg/kg & 5.8 \\
pH & 7.3 & Arsenic & 196 \\
Conductivity, dS/m & 7.37 & Barium & 0.559 \\
Saturation, \% & 53 & Beryllium & 0.522 \\
Sodium Adsorption Ratio & 2.9 & Cadmium & 15.5 \\
& & Chromium & 6.9 \\
Physical & & Cobalt & 18 \\
Bulk Density, g/cm & & \\
Moisture, wt, \% & 1.44 & Copper & 11.5 \\
& 16.9 & Lead & 0.03 \\
Soluble Salts, mg/kg & & Mercury & 0.38 \\
Calcium & & Molybdenum & 21.6 \\
Magnesium & 398 & Nickel & 1.13 \\
Sodium & 111 & Selenium & 0.4 \\
Potassium & 183 & Thallium & 19.1 \\
Sulfate-S & 214 & Vanadium & 69.8 \\
Chloride & 110 & Zinc & \\
\hline
\end{tabular}

\section{CONCLUSIONS}

Laboratory results showing changes in the concentrations of amines and the $\mathrm{T} / \mathrm{O}$ reaction products, as well as changes in toxicity, are pending. At this time, it is not possible to comment on changes in the toxicity of the soils or the composition of the leachate.

However, as of December 1, 1998, nitrogen-related data from several soil-sampling events were available. The TKN, $\mathrm{NH}_{3}-\mathrm{N}, \mathrm{NO}_{\mathrm{x}}-\mathrm{N}$, and TON results from one of the biopile plots show that TKN and TON are decreasing, while $\mathrm{NH}_{3}-\mathrm{N}$ and $\mathrm{NO}_{\mathrm{x}}-\mathrm{N}$ are increasing with time. This general pattern would be expected if biodegradation of the nitrogenous organic compounds (i.e., amines and T/O reaction products) was occurring, since ammonia is produced as a result of the biodegradation of alkanolamines and other organic nitrogenous compounds and, eventually, may be oxidized to nitrate (Gallagher et al., 1996). Therefore, based on the nitrogen-related data from the 1998 operating season, it appears that the biopile operation is successfully removing a significant portion of the MEA-related contamination from the Okotoks soil. 
Aeration of the biopile was stopped on November 16, 1998. The biopile was remixed on November 27 to break up any channels that may have formed over the summer and fall. No sampling or monitoring activities are planned for the winter months. Reactivation of the aeration system and rewetting of the biopile are currently scheduled to begin in March 1999 and continue until June 1999.

\section{REFERENCES}

American Public Health Association, 1992, Standard methods for examination of water and wastewater (18th ed.): Washington, D.C., American Public Health Association.

Gallagher, J.R., and Sorensen, J.A., 1997, An assessment of the subsurface fate of monoethanolamine at sour gas-processing plant sites - Phase II report: Calgary, Alberta, Canada, Canadian Association of Petroleum Producers, 50 p.

Gallagher, J.R., Thompson, J.S., Sorensen, J.A., and Schmit, C.R., 1996, An assessment of the subsurface fate of monoethanolamine at sour gas-processing plant sites - Phase I report: Calgary, Alberta, Canada, Canadian Association of Petroleum Producers, 60 p.

Hardisty, P.E., Dabrowski, L.S., Scroggins, R., and Weeks, P., 1990, Nature, occurrence and remediation of groundwater contamination at Alberta sour gas plants: In International Symposium on Oil and Gas Exploration and Production Waste Management Practices, 1st, New Orleans, Louisiana, Proceedings: U.S. Environmental Protection Agency.

Komex International Ltd., 1996, 1995 environmental monitoring programs at Okotoks gas plant: Unpublished report for Canadian Occidental Petroleum Ltd., Report No. KI95-3907-2-1, April.

Oilweek, 1994, Gas-processing plant capacities: Supplement to January 24 issue.

Prouty, J.L., 1994, Sprucing up natural gas: GRI GRID, Summer, p. 18-21.

Shoal Environmental Consultants Ltd., 1994, Phase II environmental site decommissioning Okotoks gas plant, Volume 1: Unpublished report for Canadian Occidental Petroleum Ltd.

Sorensen, J.A., Gallagher, J.R., Hawthorne, S.B., Thompson, J.S., Aulich, T.R., and Harju, J.A., 1998, Natural gas-sweetening wastes in the subsurface environment: Evaluation of transport and fate issues: Presented at the International Petroleum Environmental Conference.

Tannehill, C.C., and Galvin, C., 1993, Business characteristics of the natural gas- conditioning industry: Gas Research Institute Topical Report, GRI 93/0342, 183 p. 